\title{
Piridin egységet tartalmazó királis koronaéterek néhány alkalmazása
}

\author{
KUPAI József, ${ }^{\mathrm{a}}$ KISSZÉKELYI Péter, ${ }^{\mathrm{a}}$ NAGY Sándor, ${ }^{\mathrm{a}}$ KOZMA Petra ${ }^{\mathrm{a}}$ és HUSZTHY Péter ${ }^{\mathrm{a},{ }^{*}}$ \\ ${ }^{a}$ BME Szerves Kémia és Technológia Tanszék, Szent Gellért tér 4., 1111 Budapest, Magyarország
}

\section{Bevezetés}

Napjainkban széleskörü tudományos érdeklődés irányul a különböző királis vegyületek enantiomerjeinek szelektív felismerését biztosító szenzormolekulák, valamint az ezek elválasztását is lehetővé tevő szelektormolekulák kifejlesztésére. A szenzor- és szelektormolekulák szelektív komplexképző tulajdonságainak alapja a molekuláris felismerés jelensége, amely alatt azt értjük, amikor egy molekula az azt körülvevő halmazból képes szelektíven kiválasztani egy másik molekulát vagy iont, és azzal rendezett szerkezetet, komplexet alkotni.

Egészen az 1970-es évek elejéig éltek olyan nézetek, hogy az enantiomerfelismerés képességét csak a biomolekulák hordozzák. Hamarosan kiderült azonban, hogy viszonylag egyszerü, kis méretü szintetikus molekulák is rendelkezhetnek ilyen képességgel.

A koronaéterek felfedezése Pedersen nevéhez füződik, aki az első ilyen vegyületet melléktermékként izolálta. Felismerve különleges komplexképzési sajátságait, hasonló szerkezetü vegyületek tudatos szintézisébe kezdett és nagyszámú oxigéntartalmú makrociklust állított elő. ${ }^{1,} 2$ A kezdetben csak a fémionok komplexálását célzó makrociklusok előállítására és tanulmányozására irányuló kutatás hamarosan kiterjedt szerves kationokat, anionokat, valamint semleges molekulákat komplexáló makrociklusokra is. ${ }^{3,4}$

A 2016. évi kémiai Nobel-dij ${ }^{5}$ a szupramolekuláris kémia aktualitását hangsúlyozta, melynek apropóján foglaljuk össze a BME Szerves Kémia és Technológia Tanszék Szupramolekuláris Kémiai Kutatócsoportjának közelmúltban publikált eredményeit a piridino-koronaéterek néhány alkalmazási lehetőségéről.

\section{Eredmények és értékelés}

\subsection{Piridin egységet tartalmazó enantiomertiszta koronaéter alapú királis állófázisok alkalmazása enantiomerek elválasztására}

Az első olyan koronaétert, amely piridin egységet tartalmaz Cram és munkatársai állították elő 1974-ben, ${ }^{6}$ majd később ugyanez a kutatócsoport közölte először, hogy a piridin egységet tartalmazó 18-korona-6-éter típusú makrociklusok piridinjének nitrogénatomja erősebb hidrogénkötést létesít a vizsgált ammónium kationokkal, mint az éteres oxigén atom. ${ }^{7,8}$ A piridino-18-korona-6-éterek üregmérete leginkább a $\mathrm{K}^{+}$ ionok, illetve a hasonló méretü $\mathrm{NH}_{4}^{+}$ionok, így a protonált primer aminok komplexálását is lehetővé teszi. ${ }^{4}$

$\mathrm{Az}$ enantiomertiszta piridino-koronaéter-származékok enantiomerfelismerését tanulmányozva megállapították, hogy képesek különbséget tenni a királis protonált primer aminok, aminosavak és aminosav-származékok enantiomerjei között. Az enantiomerfelismerés szelektivitását fokozza, ha minél több ponton minél többféle másodlagos vagy gyenge kölcsönhatás alakul ki, ${ }^{9}$ mely esetünkben a következők:

- a hárompontos hidrogénkötés a gyürürendszer heteroatomjai és az ammóniumsó protonjai között,

- az elektronhiányos piridingyürü és a vendégmolekula elektrondús aromás részének $\pi-\pi$ kölcsönhatása,

- a sztérikus gátlás a koronaéter aszimmetriacentrumain található alkilcsoportjai és az ammóniumsó szénatomjaihoz kapcsolódó hidrogénjei között. ${ }^{10-13}$

Kutatócsoportunkban célul tüztük ki a piridingyürü 4-es helyzetében nitrogén-, illetve szénatomon át kapcsolódó oldalkar beépítésével várhatóan az addig közölteknél nagyobb enantiomer-elválasztó-képességü új, enantiomertiszta piridino-koronaéter alapú királis állófázisok előállítását, illetve azok alkalmazását protonált primer aralkilaminok enantiomerjeinek elválasztására. A kereskedelemből könnyen beszerezhető, viszonylag olcsó alapanyagokból (aceton, dietil-oxalát, fém nátrium, etanol) kiindulva a szakirodalomban közölteknél egyszerübb vagy környezetkímélőbb eljárásokat alkalmazva jutottunk a piridingyürü 4-es helyzetében nitrogén-, illetve szénatomon át kapcsolódó, trietoxiszilil végcsoportú oldalkarral szubsztituált enantiomertiszta piridino-koronaéterekhez. Ezeket szférikus HPLC minőségü szilikagélhez rögzítve $(S, S)$-CSP-1, (S,S)-CSP-2, illetve $(S, S)$-CSP-3 (1. ábra) királis állófázisokat kaptuk, melyeket négy különböző vendégmolekula [1-(1-naftil)etil-amin hidrogénperklorát (1-NEA), 1-(2-naftil)etil-amin hidrogénperklorát (2-NEA), 1-(4-brómfenil)etil-amin hidrogénperklorát (Br-PEA), 1-(4-nitrofenil)etil-amin hidrogénperklorát ( $\mathrm{NO}_{2}$-PEA)] enantiomerjeinek elválasztására alkalmaztuk. ${ }^{14}$ 


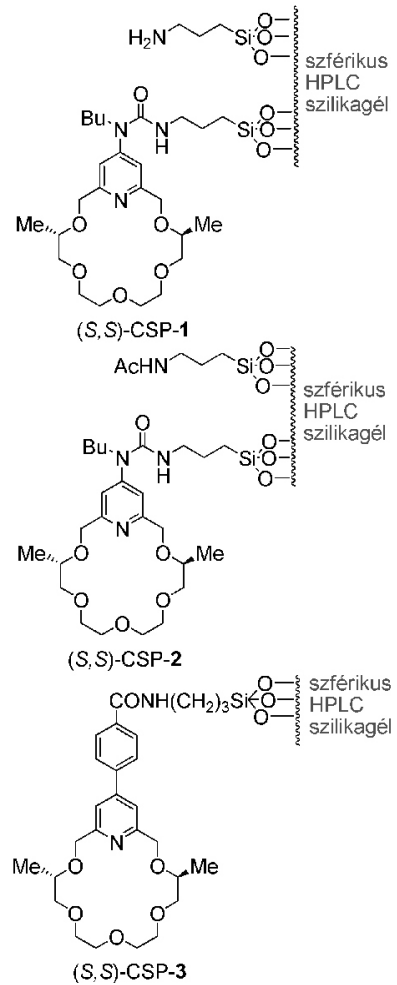

1. Ábra. Az új piridino-koronaéter alapú királis állófázisok.

Minden esetben a protonált aminok $(S)$-enantiomerjeinek volt kisebb a retenciós ideje, mint az antipódjainak. Tehát mindhárom királis állófázis heterokirális preferenciát mutatott [az $(S, S)$-koronaéter- $(R)$-aralkilammónium só komplex stabilabb a homokirális komplexhez (S,S)-koronaéter(S)-aralkilammónium só komplexhez viszonyítva]. ${ }^{11,15} \mathrm{Az}$ enantiomer-elválasztás minden esetben az 1-NEA vendégmolekula esetében volt a legsikeresebb. A legtöbb esetben magas szelektivitási $(\alpha)$ és felbontási értéket $\left(R_{\mathrm{S}}\right)$ kaptunk (1. táblázat). A leghatékonyabb elválasztást az $(S, S)$-CSP-3 királis állófázisnál tapasztaltuk, mely valószínűleg a gazdamolekula aril-piridin egysége és a vendégmolekulák aromás gyürüi között megnövekedett $\pi-\pi$ vonzó kölcsönhatásnak köszönhető. ${ }^{14}$

1. Táblázat. Az (S,S)-CSP-1, az (S,S)-CSP-2 és az (S,S)-CSP-3 királis állófázisok enantiomer-elválasztó-képességének összehasonlítása

\begin{tabular}{|c|c|c|c|}
\hline $\begin{array}{c}\text { Királis } \\
\text { állófázis }\end{array}$ & Analit & $\alpha$ & $R_{S}$ \\
\hline$(S, S)$-CSP-1 & 1-NEA & 1,67 & 1,67 \\
$(S, S)$-CSP-2 & 1-NEA & 1,78 & 4,54 \\
$(S, S)$-CSP-3 & 1-NEA & 2,49 & 9,20 \\
\hline$(S, S)$-CSP-2 & 2-NEA & 1,42 & 1,60 \\
$(S, S)$-CSP-3 & 2-NEA & 1,66 & 4,53 \\
\hline$(S, S)$-CSP-1 & Br-PEA & 1,44 & 0,85 \\
$(S, S)$-CSP-2 & Br-PEA & 1,46 & 1,00 \\
$(S, S)$-CSP-3 & Br-PEA & 1,51 & 3,58 \\
\hline$(S, S)$-CSP-1 & $\mathrm{NO}_{2}$-PEA & 1,40 & 0,61 \\
$(S, S)$-CSP-2 & $\mathrm{NO}_{2}$-PEA & 1,35 & 0,95 \\
$(S, S)$-CSP-3 & $\mathrm{NO}_{2}$-PEA & 1,40 & 3,30 \\
\hline
\end{tabular}

2.2 Molekuláris lenyomatú polimerek (MIP-ek) alkalmazása enantiomerek elválasztására, illetve szabályozott hatóanyag leadásra

A molekuláris lenyomatú polimerek (MIP-ek) képesek szelektíven megkötni egy célvegyületet vagy annak analogonjait folyadékfázisból. Ez a szelektivitás úgy érhető el, hogy a polimerizáció során a megfelelő monomerek mellett jelen van egy ún. templát vegyület, ami általában a célvegyület. A templátot a kész polimerből eltávolítva visszamaradnak a polimerben a szabad kötőhelyek, ahová a célvegyület a későbbiekben vissza tud kötődni. Általában egy kontrollpolimert is készítenek a templát jelenléte nélkül (NIP, nem imprintelt polimer). ${ }^{16-19}$

Kutatómunkánk során célunk volt egyrészt protonált primer aminok enantiomereinek elválasztására alkalmas koronaéter alapú MIP-ek szintézise, másrészt annak igazolása, hogy a hatékony működéshez szükség van a piridin-, illetve a makrogyürü jelenlétére is. ${ }^{20}$

Ehhez először a MIP-ek funkcionális monomereiként szolgáló terminális kettőskötést tartalmazó koronaétereket [(S,S)-4, 5 és 6] kellett szintetizálnunk. A makrogyürü szerepének igazolásához a fenti koronaéterek „fej részét” (7, 8) is elöállítottuk (2. ábra). ${ }^{20}$

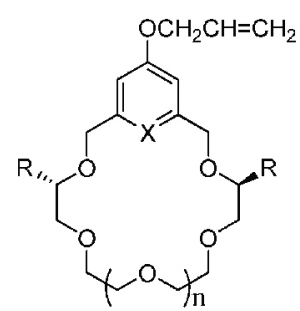

(S,S) $\mathbf{4}, X=N, \quad R=M e, n=1$ 5, $\mathrm{X}=\mathrm{CH}, \mathrm{R}=\mathrm{H}, \quad \mathrm{n}=1$ 6, $X=N, \quad R=H, \quad n=2$<smiles>C=COc1cc(COC)cc(COC)c1</smiles>

$7, \mathrm{X}=\mathrm{N}$

$$
8, \mathrm{X}=\mathrm{CH}
$$

2. Ábra. A vizsgált MIP-ek funkcionális monomerei.

A MIP készítésénél az 1-NEA-t használtuk templátként, etilénglikol-dimetakrilátot (EDMA) pedig keresztkötőként. Az elöállított öt polimer összetételét mutatja a 2. táblázat. Minden funkcionális monomerböl elöállítottunk $(R)$-1-NEA (IP1A, IP2A, IP3A, IP4A, IP5A), illetve racém 1-NEA (IP1B，IP2B，IP3B，IP4B， IP5B) templátra felépített MIP-et. Kontrollpolimerként templát távollétében is elöállítottuk az ún. NIP-eket (CP1, CP2, CP3, CP4, CP5). A MIP-eket három tényezővel szokták jellemezni. Egyrészt az ún. imprinting faktor (IF, lenyomatképzési tényezö) a templát hatását számszerúsíti azaz, hogy a MIP mennyivel jobban köti az analitot, mint a kontrollpolimer (NIP). Az enantiomer elválasztási faktor (EF) pedig a királis felismerés mértékét mutatja meg, számításakor a polimer által megkötött $R$-NEA, illetve a megkötött $S$-NEA koncentrációjának hányadosát vesszük.

A 3. ábrán látható, hogy csak a makrogyürüt tartalmazó funkcionális monomer esetén van szignifikáns különbség a MIP és a NIP kötődése között. Tehát az 1-NEA kötődéséhez szükség van a makrogyürủ jelenlétére is. Ez valószínüleg a 
polimer és a templát között létrejövő alternáló hidrogénkötésekkel, illetve a $\pi-\pi$ kölcsönhatással magyarázható (4. ábra). Ezekben az esetekben a polimerek enantiomerfelismerö-képessége (EF) és imprinting faktora (IF) is elég magas volt. Megállapíthatjuk azt is, hogy nem szükséges enantiomertiszta koronaétert alkalmazni, hogy megkülönböztessük az 1-NEA enantiomereit, ha templátként (R)-1-NEA-t alkalmazunk (ld. 3. ábrán IP2 és CP2).

2. Táblázat. A vizsgált MIP-ek és a NIP-ek összetétele.

\begin{tabular}{|c|c|c|}
\hline Polimerek & Összetétel & Srlöchiometria \\
\hline IP1A & (R)-1-NEA / $(S, S)-\mathbf{4} /$ EDMA & $1 / 1 / 40$ \\
\hline IP1B & Rac-1-NEA / $(S, S)-4 /$ EDMA & $1 / 1 / 40$ \\
\hline CP1 & $(S, S)-\mathbf{4} /$ EDMA & $1 / 40$ \\
\hline IP2A & (R)-1-NEA / 5 / EDMA & $1 / 1 / 40$ \\
\hline IP2B & Rac-1-NEA / 5 / EDMA & $1 / 1 / 40$ \\
\hline CP2 & $5 /$ EDMA & $1 / 40$ \\
\hline IP3A & $(R)-1-\mathrm{NE} \Lambda / 6 / \mathrm{EDM} \Lambda$ & $1 / 1 / 40$ \\
\hline IP3B & Rac-1-NEA / 6 / EDMA & $1 / 1 / 40$ \\
\hline C.P3 & $6 / \mathrm{FDMA}$ & $1 / 40$ \\
\hline IP4 $\Lambda$ & $(R)$-I-NEA / 7 / FDMA & $1 / 1 / 40$ \\
\hline IP4B & Rac-1-NEA / 7 / EDMA & $1 / 1 / 40$ \\
\hline CP4 & $7 /$ FDMA & $1 / 40$ \\
\hline IP5A & $(R)-1-\mathrm{NEA} / \mathbf{8} / \mathrm{EDMA}$ & $1 / 1 / 40$ \\
\hline IP5B & Rac-1-NE $\Lambda / 8 / \operatorname{EDM} \Lambda$ & $1 / 1 / 40$ \\
\hline CP5 & $8 /$ EDMA & $1 / 40$ \\
\hline
\end{tabular}

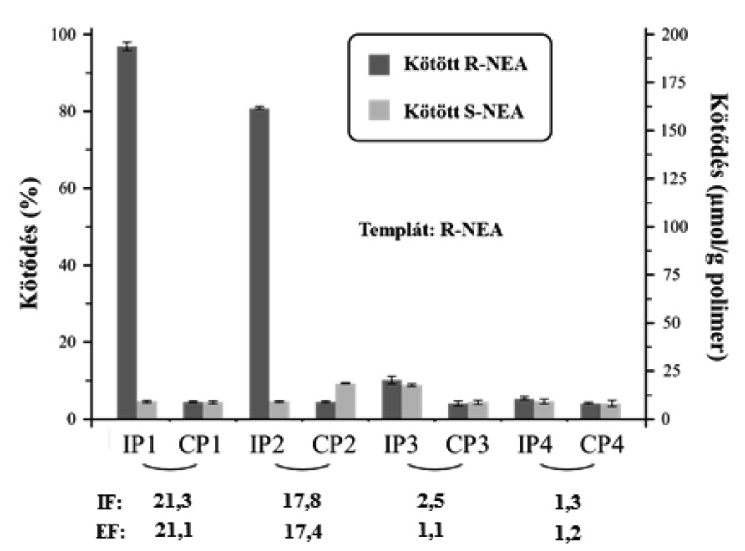

3. Ábra. Az 1-NEA enantiomereinek kötődése a MIP-eken és a NIP-eken.

A harmadik jellemző tényező a szelektivitási faktor (SF), amely meghatározza, hogy a templát (esetünkben az 1-NEA) és azzal analóg vegyületek (2-NEA, Br-PEA, $\mathrm{NO}_{2}$-PEA) kötődésében mekkora különbség van. Azt tapasztaltuk, hogy csak a makrociklust tartalmazó funkcionális monomer alapú MIP-eknél (IP1, IP2) értünk el magas (SF>25) szelektivitási faktor értéket (5. ábra). Tehát ezek a MIP-ek nemcsak arra alkalmasak, hogy megkössék az 1-NEA-t, hanem azzal a tulajdonsággal is rendelkeznek, hogy a vele analóg szerkezetü anyagokkal nem hoznak létre számottevő kölcsönhatást.

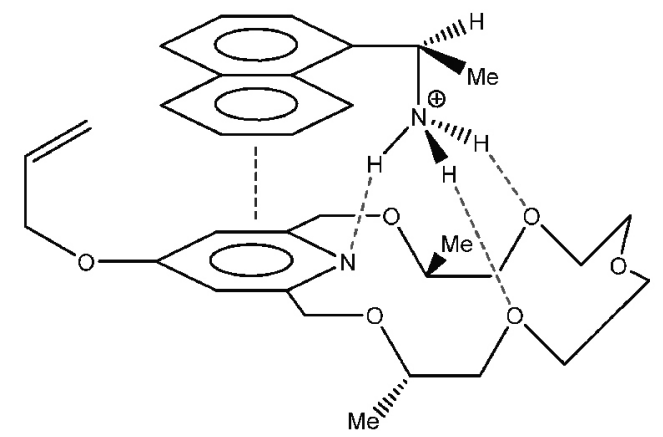

4. Ábra. Az IP1 funkcionális monomere és az 1-NEA között létrejövő kölcsönhatások.

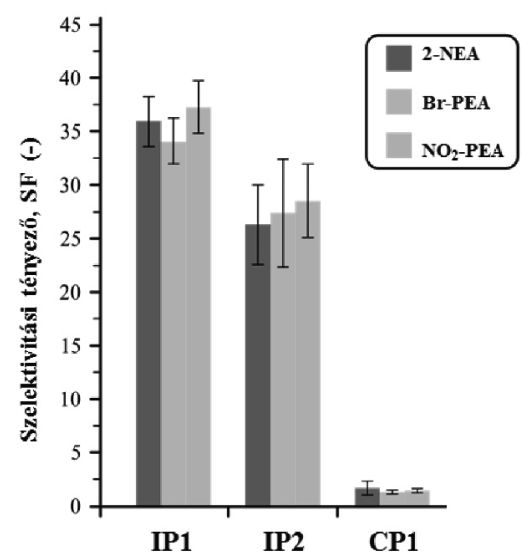

5. Ábra. Az IP1 és IP2 MIP-eknél, ill. a kontroll-polimereknél meghatározott szelektivitási tényezők.

Sikerült igazolnunk, hogy az enantiomertiszta koronaéter alapú MIP (IP1) a pH változtatásával szabályozható enantioszelektív hatóanyag leadására is alkalmas. Az 1-NEA enantiomereinek kioldódását vizsgáltuk különböző $\mathrm{pH}$ értékeknél, mint az a 6. ábrán is szerepel. Látható, hogy ebben az esetben is heterokirális preferencia tapasztalható.

Tehát az $(S, S)$ konfigurációjú koronaéter alapú MIP erősebb kölcsönhatást hoz létre az $(R)$-1-NEA-val, így az csak magasabb $\mathrm{pH}$ értéknél tud kioldódni. Ennek potenciális gyógyszeripari alkalmazása lehet, ha 1-NEA helyett gyógyszerhatóanyagot adna le a koronaéter alapú MIP a pH változtatásával.

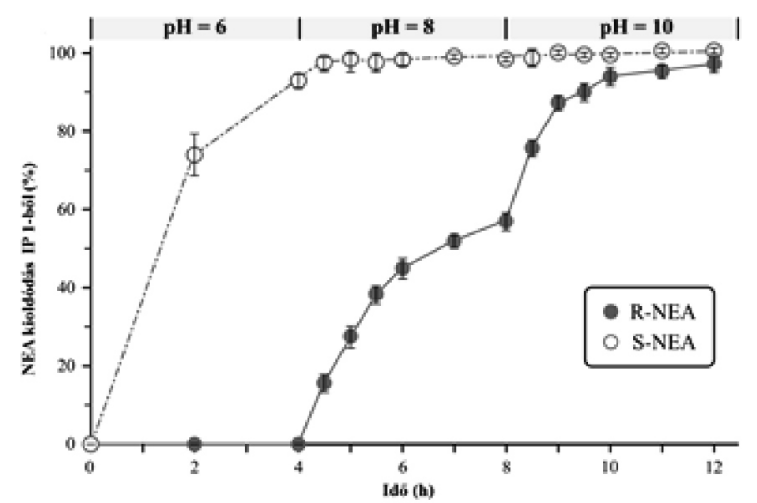

6. Ábra. Az 1-NEA enantiomereinek pH függő szabályozott kioldódása az IP1 MIP-ből. 


\subsection{Piridino-koronaéter alapú potenciális organo- katalizátorok}

Célunk volt nagy hígítású technika alkalmazásával új enantiomertiszta, bifunkcionális, potenciális organokatalizátor piridino-koronaéterek szintézise is. ${ }^{21}$

A 7. ábrán látható hat új savamid típusú piridino$[(S, S)-9-(S, S)-14], \quad$ illetve az $(S, S)-9$ és $(S, S)-12$ redukciójával piperidino- $\quad[(S, S)-\mathbf{1 5}, \quad(S, S)-\mathbf{1 6}]$ koronaétereket állítottunk elő. Ezek a makrociklusok a két savamidcsoportjuk révén hidrogénkötés donorok, a piridin-, illetve piperidingyürünek köszönhetően bázikus csoportot is tartalmaznak, és a makrogyürü királis vázként szolgál megfelelő aszimmetrikus reakciók királis indukciójához.<smiles></smiles>

(S, S)-9: $\mathrm{R}=\mathrm{Me}, \mathrm{X}=\mathrm{H}$ (S, S)-10: $\mathrm{R}=\mathrm{Me}, \mathrm{X}=\mathrm{Cl}$ (S, S)-11: R=Me, $X=\mathrm{OMe}$ $(S, S)-12: R=i B u, X=H$ (S, S)-13: $\mathrm{R}=\mathrm{BBu}, \mathrm{X}=\mathrm{Cl}$ $(S, S)-14: R=i B u, X=O M e$

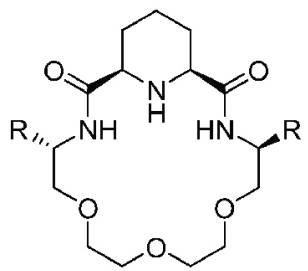

$(R, S, S, S)-15: \mathrm{R}=\mathrm{Me}$ $(R, S, S, S)-16: R=\mathrm{iBu}$
7. Ábra. Új, enantiomertiszta savamid típusú piridino-, illetve piperidino-koronaéterek mint potenciális organokatalizátorok.

A fenti koronaéterek szintézisét és visszanyerését egy viszonylag új technikával, a szerves oldószeres nanomembránszürésse ${ }^{22-26}(\mathrm{OSN})$ tettük hatékonnyá. Ez a módszer

\section{Hivatkozások}

1. Pedersen, C. J. J. Am. Chem. Soc. 1967, 89, 2495-2496. https://doi.org/10.1021/ja00986a052

2. Pedersen, C. J. J. Am. Chem. Soc. 1967, 89, 7017-7036. https://doi.org/10.1021/ja01002a035

3. Izatt, R. M. Chem. Soc. Rev. 2007, 36, 143-147. https://doi.org/10.1039/B613448N

4. Steed, J. W.; Atwood, J. L. Supramolecular Chemistry, 2nd ed.; Wiley-VCH: Chichester, West Sussex, United Kingdom, 2009. https://doi.org/10.1002/9780470740880

5. Huszthy, P. Magy. Kem. Lapja 2017, 72, 34-35.

6. Newcomb, M.; Gokel, G. W.; Cram D. J. J. Am. Chem. Soc. 1974, 96, 6810-6811. Https://doi.org/10.1021/ja00828a071 https://doi.org/10.1021/ja00828a071

7. Newcomb, M.; Timko, J. M.; Walba, D. M.; Cram, D. J. J. Am. Chem. Soc. 1977, 99, 6392-6398. https://doi.org/10.1021/ja00461a035

8. Bradshaw, J. S.; Maas, G. E.; Lamb, J. D.; Izatt, R. M.; Christensen, J. J. J. Am. Chem. Soc. 1980, 102, 467-474. https://doi.org/10.1021/ja00522a004

9. Hamilton, A. D. Hydrogen Bonding in Biological and Artifical Molecular Recognition, Advances in Supramolecular Chemistry; J. A. I. Press: Greenwich, United Kingdom, 1990, Chapter 1, pp. 2-4. képes megfelelő nyomás alkalmazásával a molekulák méret szerinti elválasztására. Bebizonyítottuk, hogy a makrociklus és a makrociklizáció kiindulóanyagainak mérete közötti különbség lehetővé teszi a reakcióban elreagálatlan kiindulóanyagok visszaforgatását. ${ }^{21}$

\section{3. Összefoglalás}

Kutatócsoportunkban az elmúlt öt évben a piridino-koronaéterek különböző alkalmazási lehetőségeit vizsgáltuk. Igazoltuk, hogy enantiomer-felismeröképességüket kihasználhatjuk enantiomerek elválasztására, ha azokat szilárd hordozóhoz rögzítjük. Három királis állófázist HPLC oszlopba töltve sikerült négy kölönbözö vendégmolekula enantiomereit hatékonyan elválasztani.

Igazoltuk, hogy ha a koronaétereket terminális kettőskötéssel látjuk el, akkor MIP-ek funkcionális monomereiként szolgálhatnak. A kapott MIP-ek képesek kemo-, illetve enantioszelektív módon megkötni a templátokat. A koronaéter alapú MIP-ek alkalmazást nyerhetnek szabályozott hatóanyagleadására is.

A piridino-koronaéterek további alkalmazási területe lehet az organokatalízis, ha hidrogénkötés donorként szolgáló savamidcsoportokat tartalmaznak. A makrociklizáció alacsony termelése javítható, ha szerves oldószeres nanomembránszürés (OSN) segítségével visszaforgatjuk az elreagálatlan kiindulóanyagokat. Ezáltal a koronaéterek előállítása és alkalmazása környezetbarátabbá tehető.

\section{Köszönetnyilvánítás}

A szerzők köszönik a K 112289 és a PD 108462 nyilvántartási számú NKFIH/OTKA támogatást.

10. Pirkle, W. H.; Pochapsky, T. C. Chem. Rev. 1989, 89, 347-362. https://doi.org/10.1021/cr00092a006

11. Izatt, R. M.; Wang, T. M.; Hathaway, J. K.; Zhang, X. X.; Curtis, J. C.; Bradshaw, J. S.; Zhu, C. Y.; Huszthy, P. J. Inclusion Phenom. Mol. Recognit. Chem. 1994, 17, 157-175. https://doi.org/10.1007/BF00711856

12. Zhang, X. X.; Bradshaw, J. S.; Izatt, R. M. Chem. Rev. 1997, 97, 3313-3361. https://doi.org/10.1021/cr960144p

13. Berthod, A. Anal. Chem. 2006, 78, 2093-2099. https://doi.org/10.1021/ac0693823

14. Kupai, J.; Antal, K.; Lévai, S.; Balogh, G. T.; Tóth, T.; Huszthy, P. Tetrahedron:Asymmetry 2012, 23, 415-427. https://doi.org/10.1016/j.tetasy.2012.04.008

15. Farkas, V.; Szalay, L.; Vass, E.; Hollósi, M.; Horváth, G.; Huszthy, P. Chirality 2003, 15, S65-S73. https://doi.org/10.1002/chir.10271

16. Molecularly Imprinted Polymers. Man-Made Mimics of Antibodies and Their Application in Analytical Chemistry; Techniques and Instrumentation in Analytical Chemistry, Sellergren, B., Ed.; Elsevier Science, Amsterdam 2001.

17. Haupt, K., Molecular Imprinting, Springer, Heidelberg 2012. https://doi.org/10.1007/978-3-642-28421-2

18. Alvarez-Lorenzo, C.,Concheiro, A., Handbook of Molecularly Imprinted Polymers, Smithers Rapra, Shrewsbury 2013. 
19. Kupai, J.; Razali, M.; Buyuktiryaki, S.; Kecili, R.; Szekely, G. Polym. Chem. 2017, 8, 666-673. https://doi.org/10.1039/C6PY01853J

20. Kupai, J.; Rojik, E.; Huszthy, P.; Szekely, G. ACS Appl Mater Interfaces 2015, 7, 9516-9525. https://doi.org/10.1021/acsami.5b00755

21. Kupai, J.; Kisszékelyi, P.; Rojik, E.; Dargó, G.; Hegedüs, L.; Bezzegh, D.; Maszler, P.; Szabó, L.; Németh, T.; Balogh, G. T.; Huszthy, P. Arkivoc, 2016, iv, 130-151. https://doi.org/10.3998/ark.5550190.p009.592

22. Szekely, G.; Jimenez-Solomon, M. F.; Marchetti, P.; Kim, J. F.; Livingston, A. G. Green Chem. 2014, 16, 4440-4473. Https://doi.org/10.1039/C4GC00701H
23. Razali, M.; Kim, J. F.; Attfield, M.; Budd, P. M.; Drioli, E.; Lee, Y. M.; Szekely, G. Green Chem. 2015, 17, 5196-5205. https://doi.org/10.1039/C5GC01937K

24. Kim, J. F.; Szekely, G.; Schaepertoens, M.; Valtcheva, I. B.; Jimenez-Solomon, M. F.; Livingston, A.G. ACS Sustainable Chem. Eng. 2014, 2, 2371-2379.

https://doi.org/10.1021/sc5004083

25. Burgal, J. S.; Peeva, L. G.; Kumbharkar, S.; Livingston, A. G. J. Membr. Sci. 2015, 479, 105-116. https://doi.org/10.1016/j.memsci.2014.12.035

26. Hermans, S.; Mariën, H.; Goethem, C. V.; Vankelecom, I. F. Curr. Opin. Chem. Eng. 2015, 8, 45-54. https://doi.org/10.1016/j.coche.2015.01.009

\section{A few applications of chiral crown ethers containing a pyridine subcyclic unit}

The aim of our research was the synthesis and applications of new enantiomerically pure selector molecules based on pyridino-18-crown-6 ethers.

Firstly, immobilization of enantiopure crown ethers on solid support by covalent bonds resulted in chiral stationary phases (S,S)-CSP-1-3 (Figure 1.). This technique combines the recyclability of the stationary phase and the selectivity of the macrocycle. Our aim was to work out a suitable synthetic route to new pyridino-crown ether-based chiral stationary phases and to apply them for separating the enantiomers of protonated primary aralkylamines. In these new CSPs, the selector molecules were attached to HPLC quality silica gel. The linking unit was bonded to the macrocycle through a nitrogen or a carbon atom. HPLC columns packed with $(S, S)$-CSP-1-3 (Figure 1.) were used for separating the enantiomers of four different guest molecules (1-NEA, 2-NEA, Br-PEA, $\mathrm{NO}_{2}$-PEA). The most retained analyte among our model compounds was 1-NEA, and the enantioselectivity achieved was the highest (Table 1.). It was found that in all cases the $(S)$-enantiomers eluted with shorter retention times than those of their antipodes, so all of the chiral stationary phases showed heterochiral preferency. Chiral stationary phase $(S, S)$-CSP-3 showed the best enantiomer separating ability for the mixtures of enantiomers of chiral amine compounds among the pyridino-crown ether-based CSPs (Table 1.). The extremely high enantioselectivity is probably due to the strong $\pi-\pi$ interaction involving the extended $\pi$-system of the aryl-substituted pyridine unit.

For the next application, three pyridine-based and two benzene-based macrocycles containing allyloxy moiety $[(S, S)-4-6]$ and their aromatic subcyclic units (7 and 8) have been synthesized and used as functional monomers for the recognition of enantiomers by molecular imprinting. We were curious about the role of chirality and macroring in imprinted polymers with enantiodiscriminative power. Five new molecularly imprinted polymers (IP1-5, see Table 2. and Figure 2.) were synthesized. During the preparation of imprinted polymers complementary cavities are left behind in the polymer after the extraction of the template. These polymers have high affinity towards the originally used molecules (used as template). It was showed that the presence of the macrocycle led to significant improvement with regards to capacity and selectivity. The performance of the imprinted polymers is highly dependent on the functionality and size of the macrocycle and the chiral nature of the template, and less dependent on the chiral nature of the macrocylic anchor (Figure 3.). It has been demonstrated, that the polymers featuring enantiomerically pure macrocyclic anchor $(S, S)-4$ provided high imprinting and enantioseparation factors, regardless of the enantiomeric purity of template 1-NEA. However, achiral macrocyclic anchor necessitates the use of enantiomerically pure template in order to achieve enantiomeric discrimination (Figure 3.). Figure 5 demonstrated that IP1 has high selectivity towards the $(R)$-1-NEA template over structurally similar amines. This can be explained by the formation of high stability $(S, S)-4-(R)-1-N E A$ heterochiral prepolymerisation complex (Figure 4.).

Furthermore, selective release of the $(R)$-1-NEA from the IP1 vehicles in response to $\mathrm{pH}$ stimuli was observed (Figure 6.). Applications as drug carriers in which release is controlled by a stimulus, such as the varying $\mathrm{pH}$ present in the intestinal tract, are envisaged. The general concepts described here can be extendable to other classes of macrocycles and enantiomers, and could be applied in chiral resolution of drugs, enantioselective sensors and $\mathrm{pH}$-responsive drug delivery systems.

Finally the preparation of six new enantiopure amide type pyridino-crown ethers $[(S, S)-9-(S, S)-\mathbf{1 4}$, see Figure 7.] was carried out. Two of them $[(S, S)-9$ and $(S, S)$-12] amide type pyridino-18-crown-6 ethers were converted into the members of a new class of crown ethers, the piperidino-18-crown-6 ethers $\quad[(R, S, S, S)-15 \quad$ and $(R, S, S, S)-16]$. According to their $\mathrm{p} K_{\mathrm{a}}$ and $\mathrm{p} K_{\mathrm{b}}$ values they are excellent bifunctional organocatalyst candidates. A preliminary study for the potential application of nanofiltration in the purification and recovery of these crown ethers was also presented. 